\title{
Determinan Kepemilikan Jamban Sehat di Desa Sukomulyo Martapura Palembang
}

\author{
Fera Novitry 1 , Rizka Agustin ${ }^{2}$ \\ Program Studi Kesehatan Masyarakat STIKES Al-Ma'arif Baturaja ${ }^{1,2}$ \\ Jl. Dr Mohammad Hatta No. 687 B Baturaja \\ Email: bunda_fw85@yahoo.co.id ${ }^{1}$,rizkagust25@ymail.com ${ }^{2}$
}

\begin{abstract}
ABSTRAK
Kondisi lingkungan yang sangat berpengaruh terhadap derajat kesehatan diantaranya penyediaan air bersih, jamban keluarga, kondisi rumah dan kondisi lingkungan pemukiman. Desa dengan akses sanitasi layak (jamban sehat) terendah di wilayah kerja UPTD Puskesmas Kotabaru yaitu: Sukomulyo (56, 5\%) Kotabaru Barat (62,9\%) Kotabaru Selatan (63, 9\%). Penelitian ini bertujuan untuk mengetahui determinan kepemilikan jamban sehat di Desa Sukomulyo. Penelitian menggunakan pendekatan cross sectional. Populasi adalah seluruh kepala keluarga yang mempunyai jamban di Desa Sukomulyo, yaitu sebanyak 472 kepala keluarga. Sampel penelitian menggunakan teknik simple random sampling, berjumlah 213 sampel. Analisis data menggunakan uji chi square untuk mengetahui hubungan variabel independen dengan variabel dependen. Hasil penelitian menunjukkan ada hubungan yang bermakna antara kepemilikan jamban sehat dengan pendidikan (p value 0, 001), pengetahuan ( $p$ value 0, 001), sikap ( $p$ value 0, 001) dan pendapatan keluarga ( $p$ value 0, 001). Kesimpulan penelitian menunjukkan bahwa ada hubungan antara pendidikan, pengetahuan, sikap dan pendapatan keluarga dengan kepemilikan jamban sehat di di Desa Sukomulyo Wilayah Kerja UPTD Puskesmas Kotabaru Kecamatan Martapura Kabupaten OKU Timur.
\end{abstract}

Kata Kunci: Jamban Sehat, Pendidikan, Pengetahuan, Sikap, Pendapatan Keluarga

\section{THE DETERMINANT OF THE OWNERSHIP OF HEALTHY LATRINES IN SUKOMULYO VILLAGE MARTAPURA PALEMBANG}

\begin{abstract}
Environmental conditions that are very influential on health status include the provision of clean water, family latrines, housing conditions and environmental conditions of the settlement. The villages with the lowest sanitation access (low latrines) in the working area of UPTD Kotabaru Health Center were Sukomulyo (56.5\%), Kotabaru Barat (62. 9\%), Kotabaru Selatan (63. 9\%). The purpose of this research is to know the determinant of the ownership of healthy latrine in Sukomulyo Village. The research used cross sectional approach. Population is all head of household having latrines in Sukomulyo Village as many as 472 head of family. The sample of research using simple random sampling technique amounted to 213 samples. Data analysis using chi square test to know the relation of independent variable with dependent variable. The results showed there was a significant correlation between the ownership of healthy latrine with education ( $p$ value 0,001), knowledge ( $p$ value 0,001), attitude ( $p$ value 0,001$)$ and family income ( $p$ value 0,001). The conclusion of the research shows that there is a correlation between education, knowledge, attitude and income of the family with the ownership of healthy latrine in Sukomulyo Village Working Area of Kotabaru Health Center of Martapura Sub-district, OKU Timur Regency.
\end{abstract}

Keyword: Healthy Latrine, Education, Knowledge, Attitude, Family Income

How to Cite: Novitry, Fera., Agustin, Rizka. (2017). Determinan Kepemilikan Jamban Sehat di Desa Sukomulyo Martapura Palembang. Jurnal Aisyah: Jurnal Ilmu Kesehatan. 2 (2), 107 - 116. 


\section{Jurnal Aisyah: Jurnal Ilmu Kesehatan 2 (2) 2017, - 108}

Fera Novitry, Rizka Agustin

\section{PENDAHULUAN}

Derajat kesehatan merupakan salah satu faktor yang sangat berpengaruh pada kualitas sumber daya manusia yang akan lebih produktif dan meningkatkan daya saing manusia. Masalah kondisi lingkungan tempat pembuangan kotoran manusia tidak terlepas dari aspek kepemilikan terhadap sarana yang digunakan. Berdasarkan data dari World Health Organization (WHO) pada tahun 2013 diperkirakan sebesar 1,1 milyar orang atau $17 \%$ penduduk dunia masih Buang Air Besar (BAB) di area terbuka, dari data tersebut sebesar $81 \%$ penduduk yang Buang Air Besar Sembarangan (BABS) terdapat di 10 negara dan Indonesia sebagai negara kedua terbanyak ditemukan masyarakat buang air besar di area terbuka, yaitu India (58\%), Indonesia (12,9\%), China (4,5\%), Ethiopia $(4,4 \%)$, Pakistan $(4,3 \%)$, Nigeria (3\%), Sudan (1,5\%), Nepal (1,3\%), Brazil $(1,2 \%)$ dan Nigeria $(1,1 \%)$ (WHO, 2014).

Berdasarkan konsep dan definisi Milenium Development Goals (MDGs) yang pada tahun 2016 dilanjutkan dengan Sustainable Development Goals (SDGs), rumah tangga dikatakan memiliki akses sanitasi layak apabila fasilitas sanitasi yang digunakan memenuhi syarat kesehatan antara lain dilengkapi dengan leher angsa, tanki septik (septic tank)/Sistem Pengolahan Air Limbah (SPAL) yang digunakan sendiri atau bersama. Persentase rumah tangga di Indonesia yang memiliki akses terhadap sanitasi layak tahun 2013 yaitu 60, 05\% dan meningkat pada tahun 2014 menjadi $61,08 \%$ dan pada tahun 2015 meningkat menjadi 62, 14\% (Kemenkes RI, 2016).

Air bersih dan sanitasi layak adalah kebutuhan dasar manusia. Salah satu poin dalam tujuan pembangunan berkelanjutan Sustainable Development Goals (SDGs) pada sektor lingkungan hidup adalah memastikan masyarakat mencapai akses universal air bersih dan sanitasi dasar yaitu jamban sehat. Sasaran global dari poin tersebut adalah pada tahun 2030 masyarakat telah mencapai akses terhadap sanitasi dan kebersihan yang memadai dan merata dan menghentikan praktik buang air besar di tempat terbuka. Di Sumatera Selatan, pada tahun 2013 persentase rumah tangga yang memiliki akses terhadap sanitasi layak yaitu $58,29 \%$, namun mengalami penurunan pada tahun 2014 menjadi 59,79\% dan pada tahun 2015 meningkat menjadi 61,30\%. Provinsi dengan persentase rumah tangga yang memiliki akses terhadap sanitasi layak tertinggi yaitu Daerah Khusus Ibukota (DKI) Jakarta dan akses terendah yaitu Papua di setiap tahunnya (Kemenkes RI, 2016).

Berdasarkan data yang diperoleh dari Dinas Kesehatan (Dinkes) Kabupaten Ogan Komering Ulu (OKU) Timur, pada tahun 2014 persentase keluarga yang memiliki jamban yaitu sebesar 62, 6\% namun hanya $34,1 \%$ yang memenuhi syarat kesehatan. Pada tahun 2015 persentase keluarga yang mempunyai jamban sehat meningkat menjadi $78,87 \%$ dan kembali mengalami peningkatan menjadi $85,63 \%$ pada tahun 2016 (Dinkes OKU Timur, 2016).

UPTD Puskesmas Kotabaru merupakan puskesmas percontohan di Kabupaten OKU Timur yang selalu menjadi tujuan bagi para tamu dari Dinas Kesehatan Provinsi Sumatera Selatan, namun persentase jamban sehat yang dimiliki warga termasuk paling rendah dibandingkan dengan puskesmas lainnya. Pada tahun 2016, persentase kepemilikan jamban yang memenuhi syarat kesehatan terendah yaitu UPTD Puskesmas Kotabaru sebesar 50\%, UPTD Puskesmas Gumawang 51, 90\% dan UPTD Puskesmas Jayapura 60\%. Persentase kepemilikan jamban yang memenuhi syarat kesehatan di wilayah UPTD Puskesmas Kotabaru telah mengalami peningkatan dibandingkan tahun sebelumnya, yaitu pada tahun 2014 hanya $3,9 \%$ jamban yang memenuhi syarat kesehatan dan pada tahun 2015 menjadi 27,0\%. 3 Desa dengan akses sanitasi layak 


\section{Jurnal Aisyah: Jurnal Ilmu Kesehatan 2 (2) 2017, - 109}

Fera Novitry, Rizka Agustin

terendah di wilayah kerja UPTD Puskesmas Kotabaru tahun 2016, yaitu: Sukomulyo (56, 5\%) Kotabaru Barat (62, 9\%) Kotabaru Selatan $(63,9 \%)$ (Dinkes OKU Timur, 2016).

Tingginya angka pertumbuhan penduduk dan rendahnya pendapatan masyarakat dapat menyebabkan semakin rumitnya masalah jamban keluarga. Dari data di atas penulis tertarik untuk melakukan penelitian tentang faktor-faktor yang berhubungan dengan kepemilikan jamban sehat.

\section{METODE PENELITIAN}

Desain penelitian yang digunakan dalam penelitian ini adalah deskriptif analitik dengan rancangan Cross Sectional. Populasi penelitian adalah seluruh kepala keluarga yang mempunyai jamban di Desa Sukomulyo yang berjumlah 472 kepala keluarga. Berdasarkan hasil perhitungan sampel menurut Iwan Ariawan dalam Notoatmodjo (2007), diperoleh sampel sebanyak 213 responden. Teknik pengambilan sampel dengan simple random sampling. Data yang digunakan data sekunder dan data primer dengan alat ukurnya berupa checklist untuk melihat kepemilikan jamban sehat, dan kuisioner untuk melihat tingkat pendidikan, pengetahuan, sikap dan pendapatan keluarga. Analisa berupa univariat dan bivariat dengan menggunakan uji chisquare.

\section{HASIL DAN PEMBAHASAN}

Tabel 1. menunjukkan persentase responden yang memiliki jamban sehat $(39,9 \%)<$ dibandingkan dengan responden yang tidak memiliki jamban sehat $(60,1 \%)$. Sebagian besar pendidikan responden termasuk dalam kategori rendah yaitu sebanyak 119 responden (55,9\%), responden dengan pengetahuan kurang yaitu sebanyak 134 responden (62,9\%), responden dengan sikap negatif sebanyak 116 responden $(54,5 \%)$ dan senagian besar responden mempunyai pendapat keluarga dengan kategori rendah yaitu 139 responden $(65,3 \%)$.

Tabel 1. Distribusi Kepemilikan Jamban Sehat, Pendidikan, Pengetahuan, Sikap dan Pendapatan Keluarga.

\begin{tabular}{lcc}
\hline \multicolumn{1}{c}{ Variabel Penelitian } & Jumlah & \% \\
\hline Kepemilikan Jamban Sehat & & \\
$\quad$ Tidak Memenuhi Syarat & 128 & 60,1 \\
Memenuhi Syarat & 85 & 39,9 \\
\hline Pendidikan & & \\
$\quad$ Rendah & 119 & 55,9 \\
$\quad$ Tinggi & 94 & 44,1 \\
\hline Pengetahuan & & \\
$\quad$ Kurang & 134 & 62,9 \\
Baik & 79 & 37,1 \\
\hline Sikap & & \\
$\quad$ Negatif & 116 & 54,5 \\
$\quad$ Positif & 97 & 45,5 \\
\hline Pendapatan Keluarga & 139 & 65,3 \\
$\quad$ Rendah & 74 & 34,7 \\
$\quad$ Tinggi & & \\
&
\end{tabular}

Berdasarkan pada tabel. 2 dapat dilihat bahwa pada variabel pendidikan diketahui proporsi responden yang memiliki jamban tidak memenuhi syarat kesehatan dengan pendidikan rendah yaitu sebesar $79,8 \%$, lebih besar dibandingkan dengan proporsi responden yang memiliki jamban tidak memenuhi syarat kesehatan dengan kategori pendidikan tinggi yaitu $35,1 \%$. Hasil uji statistik diperoleh $p$ value sebesar 0,000 dimana $p<\alpha(0,05)$, berarti ada hubungan yang bermakna antara pendidikan dengan kepemilikan jamban sehat.

Variabel pengetahuan (tabel.2) diketahui proporsi responden yang memiliki jamban tidak memenuhi syarat kesehatan dengan pengetahuan kurang yaitu sebesar 73,9\%, lebih besar dibandingkan dengan proporsi responden yang memiliki jamban tidak memenuhi syarat kesehatan dengan kategori pengetahuan baik yaitu sebesar $36,7 \%$. Hasil uji statistik didapatkan $p$ value sebesar 0,000 dimana $p<\alpha(0,05)$, berarti ada hubungan yang bermakna antara 


\section{Jurnal Aisyah: Jurnal Ilmu Kesehatan 2 (2) 2017, - 110}

Fera Novitry, Rizka Agustin

pengetahuan dengan kepemilikan jamban sehat.

Tabel 2. Hubungan Tingkat Pendidikan, Pengetahuan, Sikap, dan Pendapatan Keluarga dengan Kepemilikan Jamban Sehat.

\begin{tabular}{|c|c|c|c|c|c|c|c|}
\hline \multirow{3}{*}{ Variabel } & \multicolumn{4}{|c|}{ Kepemilikan Jamban } & \multirow{2}{*}{\multicolumn{2}{|c|}{ Total }} & \multirow{3}{*}{ p value } \\
\hline & \multicolumn{2}{|c|}{ Tidak Memenuhi Syarat } & \multicolumn{2}{|c|}{ Memenuhi Syarat } & & & \\
\hline & $\mathrm{n}$ & $\%$ & $\mathbf{n}$ & $\%$ & $\mathbf{N}$ & $\%$ & \\
\hline \multicolumn{8}{|l|}{ Pengetahuan } \\
\hline Kurang & 99 & 73,9 & 35 & 26,1 & 134 & 100 & \\
\hline Baik & 29 & 36,7 & 50 & 63,3 & 79 & 100 & 0,001 \\
\hline Jumlah & 128 & 60,1 & 85 & 39,9 & 213 & 100 & \\
\hline \multicolumn{8}{|l|}{ Pendidikan } \\
\hline Rendah & 95 & 79,8 & 24 & 20,2 & 119 & 100 & \\
\hline Tinggi & 33 & 35,1 & 61 & 64,9 & 94 & 100 & 0,001 \\
\hline Jumlah & 128 & 60,1 & 85 & 39,9 & 213 & 100 & \\
\hline \multicolumn{8}{|l|}{ Sikap } \\
\hline Negatif & 85 & 73,3 & 31 & 26,7 & 116 & 100 & \\
\hline Positif & 43 & 44,3 & 54 & 55,7 & 97 & 100 & 0,001 \\
\hline Jumlah & 128 & 60,1 & 85 & 39,9 & 213 & 100 & \\
\hline \multicolumn{8}{|c|}{ Pendapatan Keluarga } \\
\hline Rendah & 95 & 68,3 & 44 & 31,7 & 139 & 100 & \\
\hline Tinggi & 33 & 44,6 & 41 & 55,4 & 74 & 100 & 0,001 \\
\hline Jumlah & 128 & 60,1 & 85 & 39,9 & 213 & 100 & \\
\hline
\end{tabular}

Untuk variabel sikap, diketahui proporsi responden yang memiliki jamban tidak memenuhi syarat kesehatan dengan sikap negatif yaitu sebesar 73, 3\%, lebih besar dibandingkan dengan proporsi responden yang memiliki jamban tidak memenuhi syarat kesehatan dengan sikap positif yaitu sebesar 44, 3\%. Hasil uji statistik didapatkan Hasil uji statistik didapatkan $p$ value sebesar 0,001 dimana $p<\alpha(0,05)$, berarti ada hubungan yang bermakna antara sikap dengan kepemilikan jamban sehat.

Untuk variabel pendapatan keluarga, diketahui proporsi responden yang memiliki jamban tidak memenuhi syarat kesehatan dengan pendapatan keluarga yang rendah yaitu sebesar $68,3 \%$, lebih besar dibandingkan dengan proporsi responden yang memiliki jamban tidak memenuhi syarat kesehatan dengan pendapatan keluarga dengan kategori tinggi yaitu sebesar 44, 6\%. Hasil uji sttaistik didapatkan $p$ value sebesar 0,001 dimana $p$ $<\alpha(0,05)$ berarti ada hubungan yang bermakna antara pendapatan keluarga dengan kepemilikan jamban sehat.

\section{Hubungan Pendidikan Dengan Kepemilikan Jamban Sehat}

Hasil penelitian menunjukkan ada hubungan yang bermakna antara pendidikan dengan kepemilikan jamban sehat di Desa Sukomulyo ( $p$ 0.000). Hasil penelitian ini sejalan dengan penelitian yang dilakukan Azwinsyah (2014), diperoleh hasil bahwa dari 87 responden yang pendidikan tidak sekolah (100\%) tidak memiliki jamban. Responden dengan pendidikan SD yang memiliki jamban $(37,7 \%)$ dan yang tidak memiliki jamban (62, 3\%). Responden dengan pendidikan SMP yang memiliki jamban $(56 \%)$ dan yang tidak memiliki jamban (44, 0\%). Responden dengan pendidikan SMA yang memiliki jamban $(66,6 \%)$ dan yang tidak memiliki jamban $(33,4 \%)$ sedangkan responden dengan pendidikan Akademi/PT yang memiliki jamban (100\%). Dari hasil analisis statistik dengan menggunakan 


\section{Jurnal Aisyah: Jurnal Ilmu Kesehatan 2 (2) 2017, - 111}

Fera Novitry, Rizka Agustin

Fisher's Exact test diperoleh p 0,0049, artinya ada hubungan yang bermakna antara pendidikan engan kepemilikan jamban keluarga.

Notoatmodjo (2010) menjelaskan bahwa menurut teori Green, salah satu faktor yang mempengaruhi perilaku kesehatan seseorang yaitu faktor predesposisi yang meliputi pengetahuan, kepercayaan, keyakinan, nilai-nilai dan persepsi seseorang terhadap perilaku kesehatan. Pendidikan merupakan faktor yang berpengaruh dalam membentuk pengetahuan, sikap, persepsi, kepercayaan dan penilaian seseorang terhadap kesehatan. Oleh karena itu lingkungan sekolah, lingkungan fisik atau lingkungan sosial, akan sangat mempengaruhi terhadap perilaku sehat seseorang. Makin tinggi pendidikan seseorang makin mudah menerima informasi sehingga makin banyak juga pengetahuan yang dimiliki yang yang menyebabkan individu menjadi semakin sadar dan peduli terhadap kebersihan diri dan lingkungannya. Sebaliknya pendidikan yang kurang akan menghambat perkembangan sikap seseorang terhadap nilai-nilai yang baru diperkenalkan sehingga berdampak pada perilaku kesehatan (Notoatmojo, 2010).

Dari hasil penelitian ini diperoleh bahwa terdapat hubungan yang bermakna antara pendidikan responden terhadap kepemilikan jamban sehat, dimana responden yang memiliki jamban namun dalam kategori tidak sehat sebagian besar $(79,8 \%)$ adalah responden yang termasuk dalam kategori pendidikan rendah. Kenyataan di masyarakat menunjukkan bahwa responden dengan tingkat pendidikan yang rendah akan sulit memahami pesan atau informasi yang disampaikan. Semakin tinggi tingkat pendidikan seseorang semakin mudah menerima informasi sehingga banyak pula pengetahuan yang dimiliki. Pendidikan rendah yang dimiliki oleh responden menyebabkan kurangnya wawasan yang dimiliki sehingga berdampak pada kurangnya kesadaran masyarakat terhadap kesehatan lingkungannya. Sebagian besar responden tidak mengetahui tentang persyaratan jamban yang sesuai dengan standar kesehatan, sehingga mereka hanya mengutamakan kepemilikan jamban tetapi tidak memikirkan apakah jamban yang dimilikinya tersebut sudah sehat atau belum. Namun diantara responden yang mempunyai jamban tidak memenuhi syarat kesehatan terdapat $35,1 \%$ responden yang termasuk dalam kategori pendidikan yang tinggi. Hal ini dapat terjadi karena meskipun jenjang pendidikan formal yang dilalui responden sudah tergolong tinggi, namun informasi kesehatan yang diperolehnya masih kurang. Selain itu, sebagian responden terkendala dengan dana yang dimiliki untuk mebangun jamban baru yang sesuai dengan syarat kesehatan, sehingga responden tetap bertahan dengan jamban yang dimilikinya sekarang meskipun tidak memuhi syarat kesehatan. Dari hasil penelitian, terdapat 20,2\% responden yang mempunyai jamban memenuhi syarat kesehatan namun mempunyai pendidikan dengan kategori rendah. Hal ini dapat terjadi karena meskipun responden hanya mengenyam pendidikan SD atau sampai SMP yang tergolong kategori rendah, akan tetapi responden tersebut mempunyai kesadaran untuk membangun jamban sehat sehingga mendorongnya untuk berperilaku positif dengan membangun jamban sehat.

\section{Hubungan Pengetahuan dengan Kepemilikan Jamban Sehat}

Hasil penelitian di Desa Sukomulyo diketahui proporsi responden yang memiliki jamban tidak memenuhi syarat kesehatan dengan pengetahuan kurang lebih besar dibandingkan dengan proporsi responden yang memiliki jamban tidak memenuhi syarat kesehatan dengan kategori pengetahuan baik. Hasil uji statistik didapatkan ada hubungan yang 


\section{Jurnal Aisyah: Jurnal Ilmu Kesehatan 2 (2) 2017, - 112}

Fera Novitry, Rizka Agustin

bermakna antara pengetahuan dengan kepemilikan jamban sehat di Desa Sukomulyo Puskesmas Kotabaru Kecamatan Martapura. Hasil penelitian ini sejalan dengan penelitian yang dilakukan Dharma (2014) di Desa Sei Musam Kendit. Dari penelitian tersebut diperoleh hasil bahwa dari 87 responden yang berpengetahuan baik dan memiliki jamban $(66,7 \%)$ dan yang tidak memiliki jamban (33, 3\%). Sedangkan responden dengan pengetahuan yang kurang baik, yang memiliki jamban $(33,4 \%)$ dan yang tidak memiliki jamban $(66,6 \%)$. Dari hasil analisa statistik dengan menggunakan uji chi square diperoleh $(p<0,05)$, artinya ada hubungan yang bermakna antara pengetahuan dengan kepemilikan jamban keluarga.

Pengetahuan merupakan domain yang sangat penting dalam membentuk tindakan seseorang, sebab dari pengalaman dan hasil penelitian, ternyata perilaku yang didasari oleh pengetahuan akan lebih langgeng daripada perilaku yang tidak didasari oleh pengetahuan. Pengetahuan yang dimiliki oleh individu merupakan salah satu faktor yang menentukan untuk mencari dan meminta upaya pelayanan kesehatan. Semakin tinggi pengetahuan individu tentang akibat yang ditimbulkan oleh suatu penyakit, maka makin tinggi upaya pencegahan yang dilakukan (Gerungan dalam Darmawan, 2013).

Hubungan yang bermakna antara pengetahuan terhadap kepemilikan jambah sehat, dimana responden yang memiliki jamban namun tidak memenuhi syarat kesehatan sebagian besar (73, 9\%) termasuk dalam kategori pengetahuan kurang. Kurangnya pengetahuan yang dimiliki responden disebabkan karena minimnya informasi yang mereka dapat tentang sanitasi lingkungan terutama tentang jamban sehat. Yang mereka pahami hanyalah tidak diperbolehkan BAB di sembarang tempat, tanpa memikirkan persyaratan kesehatan yang harus dipenuhi oleh sarana jamban keluarga tersebut. Hal ini menyebabkan responden hanya membangun sarana tanpa memikirkan aspek-aspek persyaratan kesehatan. Namun diantara responden yang mempunyai jamban tidak memenuhi syarat kesehatan terdapat $36,7 \%$ responden yang mempunyai pengetahuan baik. Hal ini dapat terjadi karena meskipun responden tersebut mempunyai pengetahuan yang baik, pengetahuan tersebut tidak diaplikasikan dalam kehidupan sehari-hari. Hal ini berhubungan dengan masalah finansial dari keluarga.

Dari hasil penelitian, terdapat $26,1 \%$ responden yang mempunyai jamban memenuhi syarat kesehatan namun mempunyai pengetahuan yang kurang. Hal ini dapat terjadi karena adanya bias informasi penelitian karena pada sebagian rumah terdiri dari 2 (dua) kepala keluarga atau lebih. Sehingga pada saat penelitian ada responden yang pengetahuan dengan cara wawancara dilakukan pada orang yang berbeda dengan yang membangun jamban.

\section{Hubungan Sikap dengan Kepemilikan Jamban Sehat}

Hasil penelitian menunjukkan proporsi responden yang memiliki jamban tidak memenuhi syarat kesehatan dengan sikap negatif yaitu sebesar 73, 3\%, lebih besar dibandingkan dengan proporsi responden yang memiliki jamban tidak memenuhi syarat kesehatan dengan sikap positif yaitu sebesar 44, 3\%. Hasil uji statistik diperoleh ada hubungan yang bermakna antara sikap dengan kepemilikan jamban sehat di Desa Sukomulyo Puskesmas Kotabaru Martapura.

Hasil penelitian ini sejalan dengan penelitian yang dilakukan Dharma (2014) di Desa Sei Musam Kendit. Dari penelitian tersebut diperoleh hasil bahwa dari 87 responden, responden yang berpengetahuan baik dan memiliki jamban $(66,7 \%)$ dan yang tidak memiliki jamban (33, 3\%). Sedangkan responden dengan pengetahuan 


\section{Jurnal Aisyah: Jurnal Ilmu Kesehatan 2 (2) 2017, - 113}

Fera Novitry, Rizka Agustin

yang kurang baik, yang memiliki jamban $(33,4 \%)$ dan yang tidak memiliki jamban $(66,6 \%)$. Dari hasil analisa statistik dengan menggunakan uji chi square diperoleh $(p<$ $0,05)$, artinya ada hubungan yang bermakna antara pengetahuan dengan kepemilikan jamban keluarga.

Sikap didefinisikan sebagai reaksi atau respon yang masih tertutup dari seseorang terhadap suatu stimulus atau objek. Di sini dapat disimpulkan bahwa manifestasi sikap itu tidak dapat ditafsirkan terlebih dahulu dari perilaku yang tertutup. Sikap secara nyata menunjukkan konotasi adanya kesesuaian reaksi terhadap stimulus tertentu yang dalam kehidupan sehari-hari merupakan reaksi yang bersifat emosional terhadap stimulus sosial.

Sikap belum merupakan suatu tindakan atau aktifitas, akan tetapi merupakan predisposisi tindakan suatu perilaku. Sikap itu masih merupakan reaksi tertutup, bukan merupakan reaksi terbuka atau tingkah laku yang terbuka. Sikap merupakan kesiapan untuk bereaksi terhadap objek di lingkungan tertentu sebagai suatu penghayatan terhadap objek. Terjadinya perilaku yang kurang baik dari individu karena kurangnya pengetahuan dan sikap. Dalam hal ini bagaimana seharusnya keluarga mengetahui secara jelas dan benar tentang jamban yang mememuhi syarat kesehatan dan berbagai penyakit serta dampak kesehatan yang dapat disebabkan oleh tinja (Heny, 2013).

Dari hasil penelitian ini diperoleh bahwa responden yang tidak memiliki jamban sehat mempunyai sikap negatif tentang jamban sehat. Mereka menganggap biaya pembangunan jamban sehat pasti membutuhkan dana yang lebih besar sedangkan manfaat dan kegunaan antara jamban biasa dan jamban yang memenuhi syarat adalah sama, yaitu menampung kotoran manusia agar tidak mencemari lingkungan sekitar dan menyebabkan penyakit.
Sifat negatif yang dimiliki sebagian besar responden yang tidak memiliki jamban sehat tersebut disebabkan karena kurangnya informasi kesehatan mengenai jamban sehat yang sebenarnya tidaklah mahal. Namun diantara responden yang mempunyai jamban tidak memenuhi syarat kesehatan terdapat $44,3 \%$ responden yang mempunyai sikap positif. Hal ini dapat terjadi karena meskipun responden tersebut mempunyai sikap positif, namun sebagian responden mempunyai kendala pada lahan yang mereka punya. Umumnya, responden tersebut tidak memiliki lahan yang luas untuk membangun septic tank dengan jarak 10-15 m dari sumber air minum.

Sebagian lainnya mengungkapkan bahwa meskipun lahan yang dimiliki cukup untuk membangun septic tank yang letaknya lebih dari $10 \mathrm{~m}$, namun mereka sudah terlanjur membangun sarana air minum dan septic tank tersebut dan tidak bisa diubah sesuai syarat kesehatan karena biaya yang harus dikeluarkan lagi untuk biaya perbaikan. Dari hasil penelitian, terdapat 26,7\% responden yang mempunyai jamban memenuhi syarat kesehatan namun mempunyai sikap negatif. Hal ini dapat terjadi di lokasi penelitian terdapat bebrapa rumah yang baru dibangun. Hampir seluruh rumah yang baru dibangun tersebut otomatis membangun jamban permanen yang sehat meskipun responden yang mempunyai rumah tersebut tidak mempunyai sikap positif.

\section{Hubungan Pendapatan Keluarga dengan Kepemilikan Jamban Sehat}

Hasil penelitian diketahui proporsi responden yang memiliki jamban tidak memenuhi syarat kesehatan dengan pendapatan keluarga yang rendah yaitu sebesar $68,3 \%$, lebih besar dibandingkan dengan proporsi responden yang memiliki jamban tidak memenuhi syarat kesehatan dengan pendapatan keluarga dengan kategori tinggi yaitu sebesar 44, 6\%. Hasil uji sttaistik didapatkan ada hubungan yang 


\section{Jurnal Aisyah: Jurnal Ilmu Kesehatan 2 (2) 2017, - 114}

Fera Novitry, Rizka Agustin

bermakna antara pendapatan keluarga dengan kepemilikan jamban sehat di Desa Sukomulyo Puskesmas Kotabaru Martapura.

Hasil penelitian ini sejalan dengan hasil penelitian yang dilakukan Widowati (2015) yang bertujuan untuk mengetahui hubungan karakteristik pemilik rumah dengan perilaku Buang Air Besar Sembarangan (BABS) di wilayah kerja Puskesmas Sambungmacan II, diperoleh hasil babhwa ada hubungan yang signifikan antara pendapatan dengan kepemilikan jamban dan perilaku BABS di wilayah kerja Puskesmas Sambungmacan II $(p 0,001)$ (Widowati, 2015).

Tingkat pendapatan seseorang untuk memenuhi kebutuhan hidup atau status ekonomi yang baik akan berpengaruh pada fasilitas yang diperoleh atau berusaha dipenuhi. Apabila tingkat pendapatan baik, maka fasilitas kesehatan mereka khususnya di dalam rumahnya akan terjamin, misalnya dalam penyediaan jamban keluarga. Rendahnya pendapatan merupakan rintangan bagi kalangan tidak mampu untuk memenuhi fasilitas kesehatan sesuai kebutuhan. Dengan demikian, dapat disimpulkan bahwa pendapatan keluarga menentukan ketersediaan dan keterjangkauan fasilitas kesehatan. Semakin tinggi pendapatan keluarga, semakin baik fasilitas dan cara hidup anggota keluarga. Pendapatan merupakan faktor yang menentukan kualitas dan kuantitas fasilitas kesehatan di suatu keluarga (Hermin, 2013).

Berdasarkan hasil penelitian ini diperoleh bahwa terdapat hubungan yang bermakna antara pendapatan keluarga terhadap kepemilikan jamban sehat, dimana responden yang memiliki jamban namun tidak memenuhi syarat kesehatan sebagian besar $(68,3 \%)$ memiliki pendapatan keluarga yang termasuk dalam kategori rendah. Faktor ekonomi yang masih rendah menyebabkan responden tidak sanggup untuk membangun jamban yang sesuai dengan kriteria jamban sehat.

Keluarga yang pendapatannya rendah kurang partisipasinya dalam kesehatan lingkungan, karena bagi mereka kelangsungan hidup lebih penting daripada melakukan langkah-langkah terobosan baru yang belum jelas hasilnya. Namun diantara responden yang memiliki jamban tidak memenuhi syarat kesehatan terdapat $44,6 \%$ responden yang termasuk dalam pendapatan keluarga yang tinggi. Hal ini dapat terjadi karena meskipun responden tersebut memiliki pendapatan yang tergolong tinggi, namun kurangnya kesadaran tentang pentingnya sarana sanitasi dasar membuatnya enggan untuk memperbaiki status kesehatan keluarganya.

Sebagian besar responden dengan pendapatan keluarga tinggi tersebut sudah mempunyai jamban permanen hanya saja terdapat beberapa kriteria yang tidak terpenuhi untuk menjadikan jamban di rumahnya menjadi jamban memenuhi syarat, salah satunya dan yang paling sering dijumpai di tempat penelitian adalah saluran pembuangan dari jamban keluarga yang letaknya berdekatan dengan sumber air. Dari hasil penelitian, terdapat 31,7\% responden yang mempunyai jamban memenuhi syarat kesehatan meskipun mempunyai pendapatan yang rendah. Hal ini dapat terjadi karena pada beberapa responden penelitian, terdapat responden yang mempunyai rumah yang pembangunannya mendapat bantuan dari orangtua atau keluarganya, sehingga meskipun secara ekonomi termasuk dalam kategori pendapatan kurang namun responden tersebut dapat membangun dan memiliki jamban sehat.

\section{SIMPULAN DAN SARAN}

Berdasarkan hasil penelitian yang dilakukan, distribusi responden yang memiliki jamban tidak memenuhi syarat yaitu sebanyak $60,1 \%, \quad$ distribusi pendidikan responden termasuk dalam 


\section{Jurnal Aisyah: Jurnal Ilmu Kesehatan 2 (2) 2017, - 115}

Fera Novitry, Rizka Agustin

kategori rendah yaitu sebanyak 55,9\%, distribusi responden dengan pengetahuan kurang yaitu 62,9\%), distribusi responden dengan sikap negatif sebanyak $54,5 \%$ dan distribusi responden yang mempunyai pendapat keluarga dengan kategori rendah yaitu 65,3\%. Ada hubungan antara kepemilikan jamban sehat dengan pendidikan ( $p$ value 0,001), pengetahuan ( $p$ value 0,001), sikap ( $p$ value 0,001), dan pendapatan keluarga ( $p$ value 0,001) di Desa Sukomulyo.

Beberapa saran yang dapat diberikan diantaranya kepada petugas kesehatan agar dapat lebih kreatif dalam memberikan edukasi kesehatan mengenai jamban sehat, misalnya menggunakan metode pemicuan dengan menggunakan alat bantu berupa poster alur penularan penyakit yang disebabkan oleh tinja manusia serta melakukan observasi langsung ke tempattempat yang biasanya digunakan masyarakat untuk BAB sembarangan. Dengan kegiatan tersebut diharapkan kesadaran masyarakat dapat tergugah dan mereka dengan sendirinya dapat menyadari masalah kesehatan yang dapat ditimbulkan dari jamban yang tidak sehat. Selain itu, petugas kesehatan juga diharapkan bekerja sama dengan lintas sektor seperti dengan Tentara Nasional Indonesia (TNI) yang sedang aktif menjalankan program jambanisasi untuk membangun jamban di desa-desa.

Bagi sanitarian dan petugas kesehatan lingkungan dapat lebih berperan serta dalam meningkatkan kesadaran masyarakat tentang pentingnya sanitasi lingkungan dan jamban keluarga yang memenuhi syarat kesehatan.

Kader kesehatan dan tokoh masyarakat dapat menjadi teladan yang baik dalam pemanfaatan jamban sehat sehingga masyarakat dapat mengadaptasi perilaku positif tersebut. Selain itu, para kader kesehatan dapat lebih aktif lagi mengikuti kegiatan perkumpulan warga desa untuk melakukan sosialisasi tentang pemanfaatan jamban sehat. Hal ini sebagai salah satu kegiatan yang dapat dilakukan dalam program "kader pintar" di wilayah UPTD Puskesmas Kotabaru, sehingga para kader tidak hanya berperan dalam kegiatan pemantauan tumbuh kembang balita saja tetapi berperan aktif dalam kegiatan kesehatan lingkungan.

Penelitian selanjutnya dapat menyertakan variabel yang lain seperti peran serta tokoh masyarakat dalam kepemilikan dan pemanfaatan jamban sehat. 


\section{Jurnal Aisyah: Jurnal Ilmu Kesehatan 2 (2) 2017, - 116}

Fera Novitry, Rizka Agustin

\section{DAFTAR PUSTAKA}

Azwinsyah, dkk. (2014). Faktor-Faktor yang Berhubungan dengan Rendahnya Kepemilikan Jamban Keluarga dan Personal Hygiene dengan Kejadian Diare di Desa Sei Musam Kendit Kecamatan Bahorok Kabupaten Langkat Tahun 2014. http://download.portalgaruda.org/ (diakses 8 April 2017).

Darsana. (2012). Faktor-Faktor yang Berhubungan dengan Kepemilikan Jamban Keluarga di Desa Jehem Kecamatan Tembuku Kabupaten Bangli Tahun 2012. Jurnal Kesehatan Lingkungan Vol 4 No 2, November 2014 http://poltekkesdenpasar.ac.id/ (diakses 8 April 2017).

Dinas Kesehatan Kabupaten Ogan Komering Ulu Timur. (2016). Profil Kesehatan Kabupaten OKU Tahun 2015.

Dinas Kesehatan Provinsi Sumatera Selatan. (2014). Profil Kesehatan Provinsi Sumatera Selatan Tahun 2013. Palembang: Dinas Kesehatan Provinsi Sumatera Selatan.

. (2015). Profil Kesehatan Provinsi Sumatera Selatan Tahun 2014. Palembang: Dinas Kesehatan Provinsi Sumatera Selatan.

Dharma. (2014). Faktor-Faktor yang Berhubungan dengan Rendahnya Kepemilikan Jamban Keluarga dan Personal Hygiene dengan Kejadian Diare di Desa Sei Musam Kendit Kecamatan Bahorok Kabupaten Langkat Tahun 2014.

Kementerian Kesehatan Republik Indonesia. (2013). Profil Kesehatan Indonesia Tahun 2012. Jakarta:
Kementerian Kesehatan Republik Indonesia.

. (2014). Profil Kesehatan Indonesia Tahun 2013. Jakarta: Kementerian Kesehatan Republik Indonesia.

(2014). Peraturan Menteri Kesehatan Nomor 3 Tahun 2014 Tentang Sanitasi Total Berbasis Masyarakat. Jakarta: Kementerian Kesehatan Republik Indonesia.

. (2014). Informasi Pilihan Jamban Sehat. Water and Sanitation Program East Asia and the Pacific (WSP-EAP). Jakarta: Kementerian Kesehatan Republik Indonesia.

. (2015). Profil Kesehatan Indonesia Tahun 2014. Jakarta: Kementerian Kesehatan Republik Indonesia.

Kusnoputranto, H. (2013). Kesehatan Lingkungan: Jamban di Indonesia. Jurnal Kesehatan Lingkungan. Vol. 5, No.4, November 2013. http://etd.repository.ui.ac.id/ (diakses 7April 2017).

Notoatmodjo, S. (2010). Kesehatan Masyarakat Ilmu dan Seni. Jakarta: Rineka Cipta.

WHO. (2014). Progres Sanitasi dan Air Minum - Progress on Sanitation and Drinking-Water: Update. Geneva: WHO 2010. 